\title{
Three-dimensional slope stability model of the Turaida castle mound
}

\author{
Kārlis Kukemilks a and Mārtinš̌ Vilnītis ${ }^{\mathrm{b}}$ \\ a Department of Geology, University of Trier, Behringstraße 21, D-54296 Trier, Germany; Kukemilks.karlis@inbox.lv \\ ${ }^{\mathrm{b}}$ Construction Technology Department, Faculty of Civil Engineering, Riga Technical University, Ķīpsalas Street 6B, Riga, LV-1048, \\ Latvia; martins.vilnitis@rtu.lv
}

Received 28 November 2020, accepted 13 May 2021, available online 21 September 2021

\begin{abstract}
The state-of-the-art finite element software Plaxis 3D was applied in a real-world study site of the Turaida castle mound to investigate the slope stability of the mound and understand the mechanisms triggering landslides there. During the simulation, the stability of the castle mound was analysed and the most landslide-susceptible zones of hillslopes were determined. The 3D finite-element stability analysis has significant advantages over conventional 2D limit-equilibrium methods where locations of 2D stability sections are arbitrarily selected. Two modelling scenarios of the slope stability were elaborated considering deep-seated slides in bedrock and shallow landslides in the colluvial material of slopes. The model shows that shallow slides in colluvium are more probable. In the finite-element model, slope failure occurs along the weakest zone in colluvium, similarly to the situation observed in previous landslides in the study site. The physical basis of the model allows results to be obtained very close to natural conditions and delivers valuable insight in triggering mechanisms of landslides.
\end{abstract}

Key words: landslides, slope stability modelling, numerical models, Gauja spillway valley.

\section{INTRODUCTION}

In the Baltic countries, landslides are commonly present in river valleys because steep slopes increase landslide risk there. Other investigated landslide-triggering factors are the low shear strength of soils (Soms 2006; Kohv et al. 2009, 2010; Kukemilks \& Saks 2013), slope undercutting by the river (Kohv et al. 2010; Kukemilks 2018) and preferential groundwater flow (Soms 2006; Kukemilks et al. 2018).

The study area is situated in the ancient Gauja spillway valley, Central Latvia. This territory was covered by Scandinavian ice sheets several times, including the late Weichselian glaciation (Zelčs et al. 2011). During the late Weichselian glaciation, the glacier retreated northwestwards, meltwaters were trapped between the ice margin and northern slope of the Vidzeme upland forming icedammed lakes (Āboltiņš 1971; Zelčs \& Markots 2004). The drainage of the ice-dammed lakes incised an up to $70 \mathrm{~m}$ deep proglacial spillway in the location of the study area (Zelčs \& Markots 2004). Landscape-forming processes are still ongoing during Holocene time, however, no comprehensive regional studies are available about the dynamics of these processes during different periods of the Holocene. It has been supposed that the deep-incised tributary valleys and even the largest gullies may have originated already during the last deglaciation (Kukemilks \& Saks 2013).

The steep valley slopes are dissected by a dense gully network; landslide processes are present both on the banks of the gullies and the main valley (Kukemilks \& Saks 2013). Several recent gullying and mass wasting processes have been observed (Kukemilks \& Saks 2013). In February 2002, three landslides occurred on the slopes of the Turaida castle mound. Two landslides buried the local motor road and threatened the historical monument Turaida medieval castle (Kukemilks et al. 2018). It should be added that these landslides happened within a couple of days on different sides of the castle mound (Fig. 1).

The lithology of the castle mound is characterized by an alternating sequence of Devonian clayey and sandy sedimentary rocks which are overlain by glacial till and colluvium/anthropogenic deposits. Two Quaternary sequences, colluvium/anthropogenic deposits on the slopes and glacial till in the topmost part, are present in the castle mound. Quaternary deposits are underlain by Devonian bedrock, represented by an alternating sequence of sandy and clayey layers. The slopes of the castle mound are 

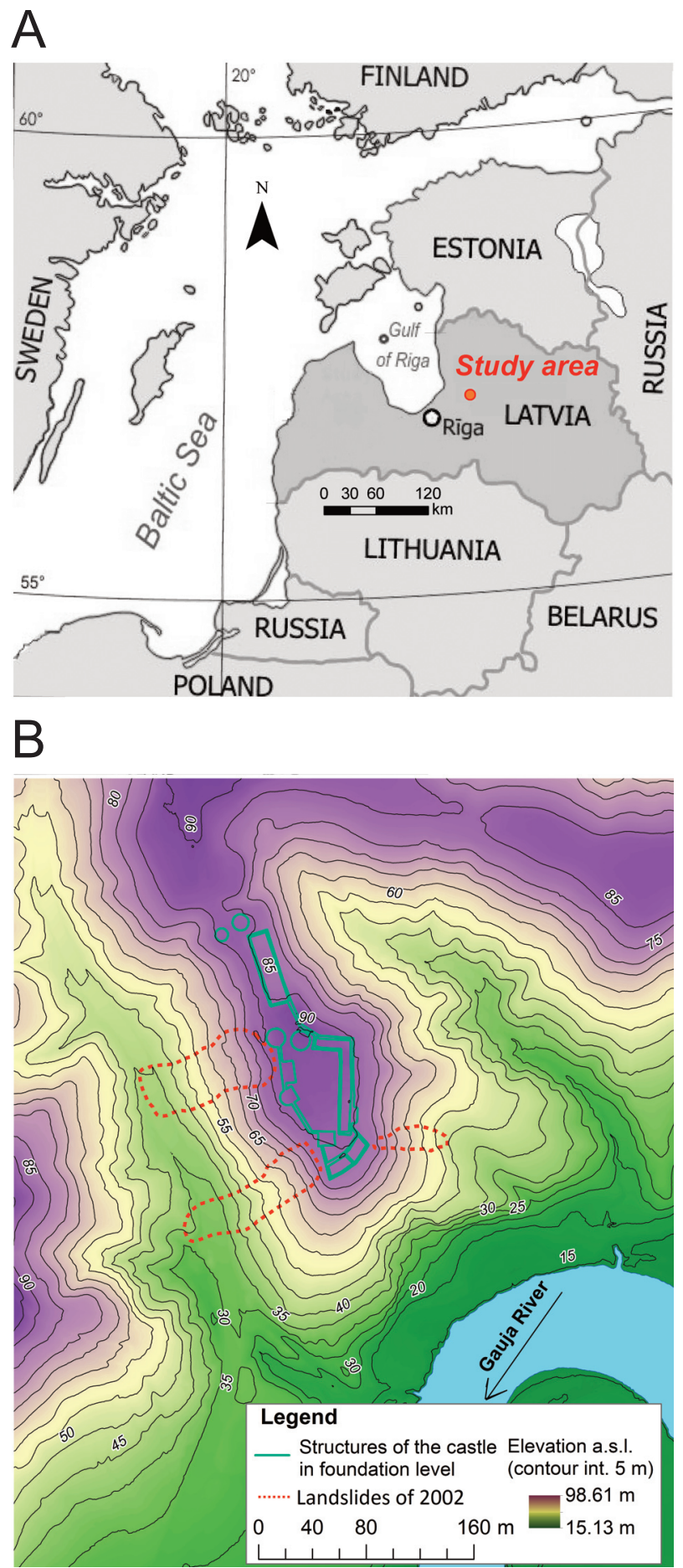

depth of the colluvium/anthropogenic deposits varies largely, ranging from 0.05 to $5 \mathrm{~m}$ depending on the location (Mūrnieks et al. 2002). During the landslides of 2002, colluvium and the anthropogenic cover were the main landslide-forming material (Kukemilks et al. 2018).

This study investigates the slope stability of the Turaida castle mound by applying the state-of-the art geomechanical model Plaxis 3D. The aim of the study is to determine the triggering mechanisms responsible for the landslides of 2002 and to find out whether the landslide risk still exists. The study is complementary to the previous research by Kukemilks et al. (2018), where a 3D hydrogeological model of the Turaida castle mound was elaborated and the slope stability in separate sections was estimated using a 2D limit-equilibrium model. However, recent advances of numerical simulators allow for 3D finite-element stability modelling, which is a precondition for complete understanding of physical processes causing landslide formation.

Colluvial material was not considered in the model by Kukemilks et al. (2018) with an assumption that foundations of the historical building are supported on bedrock and therefore slides in colluvium cannot threaten it. However, landslides in colluvial material can cause damage to adjacent infrastructure, decrease overburden load and subsequently destabilize the foundations of the castle. Therefore, in this publication shallow landslides in colluvial material were considered in a separate model as well.

\section{NUMERICAL SIMULATORS}

Kukemilks et al. (2018) analysed 2D slope stability sections of the Turaida castle mound with the limitequilibrium method. This method is still commonly applied in geotechnical engineering (Fredlund et al. 2017). Due to recent advances of numerical modelling, also the newest 3D finite-element slope stability simulators have found an application both in industry and research ( $\mathrm{Lu} \&$ Godt 2013; Fredlund et al. 2017).

The limit-equilibrium method emerged at the beginning of the 20th century (Das 1998; Lu \& Godt 2013). The limit-equilibrium approaches determine the force and moment equilibrium of a rigid soil body that is subject to implicit normal and shear stress controlled by landslide's morphology. Slope stability from limit-equilibrium calculation can be expressed as a relation between the average shear strength of the soil and the average shear stress developed along the potential failure surface (Das 1998). Both $2 \mathrm{D}$ and $3 \mathrm{D}$ limit-equilibrium methods are available for slope stability calculations (Kalatehjari \& Ali 2013).

Although 2D simulators are robust and provide fast numerical solutions, it has been shown that $2 \mathrm{D}$ analysis 
frequently underestimates slope stability (Gens et al. 1988; Fredlund et al. 2017). Safety factors from 3D analysis are more realistic because they consider complete morphology of the sliding body. When applying both 2D and 3D limit-equilibrium analysis, a predetermined shape of the failure surface is assumed (Kalatehjari \& Ali 2013). For instance, a cylinder with conical or ellipsoidal ends (Baligh \& Azzouz 1975), and a conical, wedge-shaped (Hovland 1977) or spherical (Cheng \& Yip 2007) sliding surface can be modelled. Contrary to limit-equilibrium approaches, the newest finite-element models allow for stress and strain calculation in the hillslope. Initial assumptions about a sliding surface are avoided because slope failure happens naturally through zones where low shear strength occurs in the hillslope (Griffiths \& Lane 1999; Lu \& Godt 2013).

Owing to irregular surface topography and heterogeneous geological and hydrogeological conditions, it is hardly possible to determine the most critical hillslope section at Turaida by applying 2D analysis. The finiteelement method provides an adequate solution for such a complex slope stability problem as the Turaida castle mound. The stress and strain distribution in the complete castle mound is calculated by considering complex topographical and geological settings, and the most critical zone from the stability viewpoint is identified.

The state-of-the-art 3D finite element model Plaxis 3D was used in the study site because this model has various applications in slope stability estimation. Plaxis 3D determines the global safety factor of hillslopes by applying the shear strength reduction method (van der Sloot 2020). The safety factor is expressed as a ratio of available shear strength to minimum shear strength required for equilibrium (van der Sloot 2020).

In the cases when the safety factor is expressed through the standard Mohr-Coulomb failure criterion,

$$
\text { Safety factor }=\frac{c-\sigma_{n} \tan (\varphi)}{c_{r}-\sigma_{n} \tan \left(\varphi_{r}\right)} .
$$

Here $c$ and $\varphi$ are available strength parameters, $c_{r}$ and $\varphi_{r}$ are reduced shear strength parameters sufficient to maintain equilibrium and $\sigma_{n}$ is the actual normal stress component.

Both shear parameters are reduced in the same proportion until a constant value is attained for a number of successive load steps:

$$
\frac{c}{c_{r}}=\frac{\tan (\varphi)}{\tan \left(\varphi_{r}\right)}=\sum M s f
$$

Consequently, the multiplier $\sum M s f$ is defined as a safety factor of the hillslope (van der Sloot 2020).

If the available shear strength in the hillslope is less than the minimum shear strength required for equilibrium, the safety factor is $\leq 1.0$, meaning that slope rupture should occur. When interpreting the results of modelling, also safety factors slightly over 1.0 are considered as unsafe, because external environmental and anthropogenic impacts or uncertainties of intrinsic geomechanical properties can lead to a lower safety factor. For the calculation of slope safety in geoengineering, a design code, e.g. Eurocode 7, should be used. Partial factors to actions or to geotechnical parameters or resistances are applied, resulting in a safety reserve for the cases when the slope stability can decrease due to internal or external stability reducing factors acting on the slope.

However, the estimates of this study do not rely on any design standard. This approach was selected because the aim of the study was to investigate the actual stability of the castle mound and determine the causes which may initiate landslide events in the future. For our case study, the application of partial factors would result in a reduced slope safety factor, which would not allow us to estimate the actual stability of the castle mound. For instance, if the actual modelled safety factor was slightly above 1.0 , we would interpret it as an endangered slope where minor impacts, such as increase in groundwater table, could decrease the safety factor below 1.0 and cause slope rupture. However, if we applied partial factors in the same slope stability calculation, probably the estimated safety factor would decrease below 1.0, meaning that the slope has already exceeded its available shear strength, which does not correspond to the situation in the real-world.

\section{MODEL SETUP}

The stratigraphical model of the castle mound is based on one borehole in the central part of the castle mound which was drilled during the field investigation in 2002 and a set of shallow test borings on the western and eastern slopes (Mūrnieks et al. 2002). Several assumptions were necessary to create and successfully run the 3D model. Layer interfaces were assumed horizontal because the integration of dome-shaped layer surfaces and irregular sedimentary leans, determined during field investigations (Mūrnieks et al. 2002), would overcomplicate the model's geometry. Thin layers $(<0.5 \mathrm{~m})$ were not considered in the analysis because they caused crashes during mesh generation. A relatively coarse model's surface was applied due to meshing restrictions because the castle mound has complex and irregular topography, therefore generalization of topographical shapes was necessary. For numerical reasons, it was not possible to build a model of a complete layer sequence overlain by colluvial material. Therefore, two modelling scenarios were considered - a parallel layer sequence without colluvial material (Fig. 2A) and with colluvial material overlying a homogeneous sublayer (Fig. 2B). 

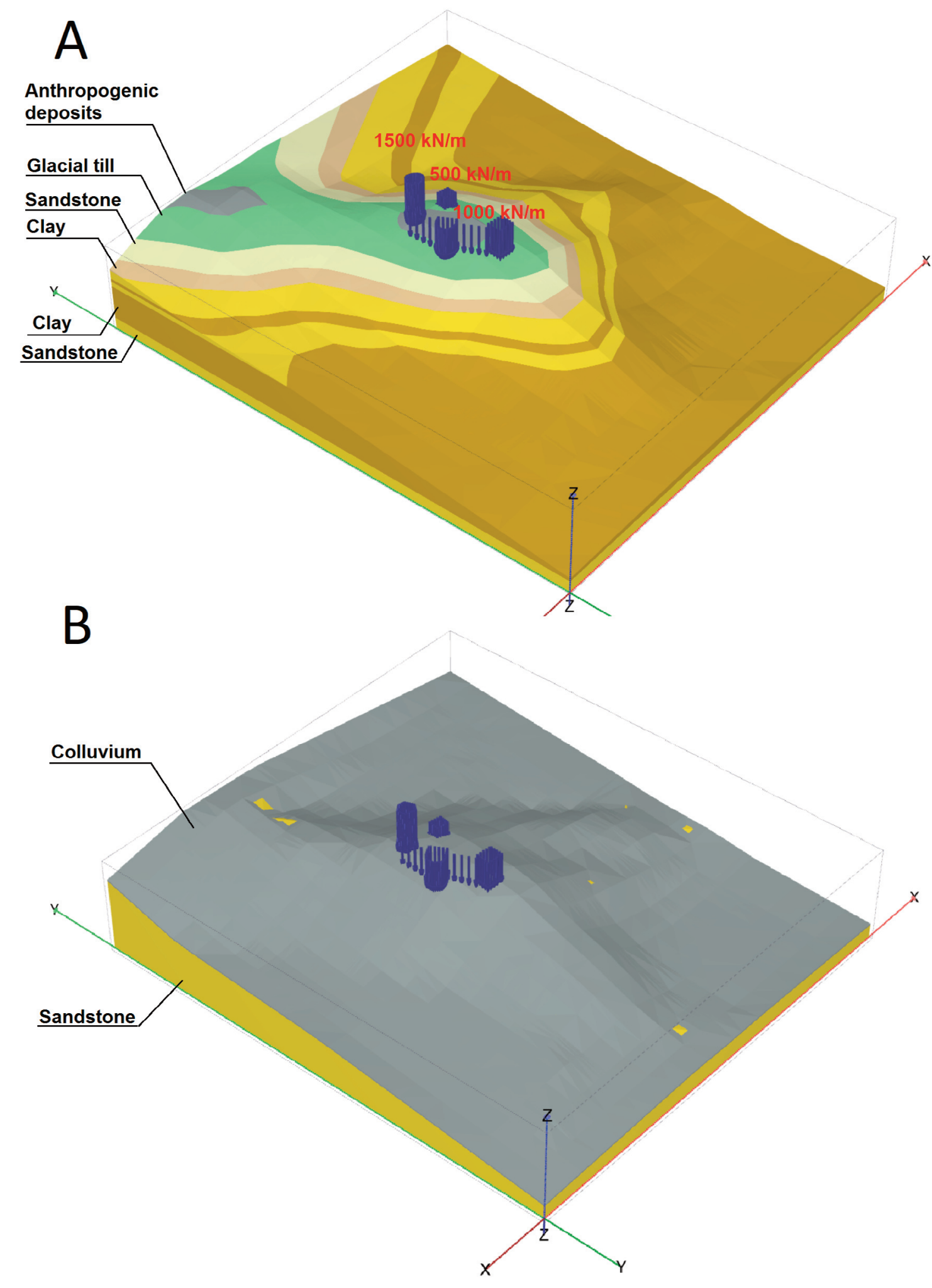

Fig. 2. Geological model of the castle mound without colluvial material (A) and with colluvial material and a homogeneous sublayer (B). 
A constant depth of colluvium equal to $1.5 \mathrm{~m}$ was assumed, which is an approximate mean thickness of colluvium strata, because no exact information about the depth of colluvium on slopes is available. In real-world conditions, the depth of colluvium has pronounced variations in different locations of the castle mound, varying from 0.05 to $5 \mathrm{~m}$ in separate testing points which were not exactly determined. Uniformly distributed loads with a magnitude of 500,1000 and $1500 \mathrm{kN} / \mathrm{m}$ were added to the model. These loads, resulting from structures of the medieval castle, represent the estimated force acting on soil massive.

The geomechanical properties of the layers determined through laboratory testing (Mūrnieks et al. 2002; Kukemilks et. al 2018) are displayed in Table 1.

Soil samples were taken from a drillcore in the central part of the castle mound and shear strength parameters were determined using a shear-box test. The geomechanical properties of colluvium, illustrated in Fig. 3, were derived from cone-penetration tests by applying correlations (Mūrnieks et al. 2002). One can observe emphasized variation in geomechanical properties. For instance, the cohesion of colluvium varies from 2 to $47 \mathrm{MPa}$. Variation in the properties of colluvium is especially high due to the heterogeneity of these sediments (Fig. 3). Colluvium may contain anthropogenic deposits, especially in the upper part of the castle mound. For the final model setup, geomechanical properties from one cone-penetration test performed in the SE part of the castle mound were used. This was done because through repeated model runs the most landslide-susceptible zone of the castle mound was identified there, therefore also geomechanical parameters were taken in the proximity of this zone.

The hydrogeology of the mound is controlled by the alternation of permeable Devonian sandy and less permeable Devonian clayey layers which cause the formation of perched groundwater tables. Hydrogeological impacts causing increased pore-water pressures are one of the most possible triggers responsible for landslides which occurred in 2002 (Kukemilks et al. 2018). Recent research has shown that negative pore-water pressure or suction can increase slope stability under dry conditions. However, suction decreases after heavy rainfalls and thus shallow landslides may occur (Lu \& Godt 2013). In the case of the Turaida castle mound, shallow landsliding in colluvial material is highly possible due to high heterogeneity and low shear strength of the sediments present in the castle mound. Increase in soil shear strength due to suction depends on variable climatic conditions, therefore suction is not applicable as a long-term slope stability increasing factor. Suction or negative pore-water pressure was ignored in the Plaxis 3D model, to avoid overestimation of the slope stability due to the aforementioned effect. When applying the Ignore suction option in Plaxis stability simulation, the degree of soil saturation is automatically set to 1.0 (van der Sloot 2019).

\section{RESULTS}

Two scenarios of the slope stability model were used, which allowed consideration of diverse sliding mechanisms: (1) deep-seated landslides in bedrock and (2) shallow slides in colluvium (Fig. 2). A 3D slope stability model for the modelling scenario analysing bedrock stability is illustrated in Fig. 4. The model shows that the most probable slope failure occurs on the western part of the castle mound at the foot of the defence tower. The minimum safety factor $\sum M s f$ equals 1.626 .

The section through the landslide-susceptible zone illustrates the sliding mechanism in bedrock (Fig. 5). Stresses caused by the load from castle's defence structures are also considered in analysis. Loads in the upper part of the castle mound are increasing stresses in the hillslope and reducing its stability.

The second slope stability modelling scenario considers shallow landslides in colluvial material and anthropogenic deposits. The stability of $1.5 \mathrm{~m}$ thin colluvium on

Table 1. Geomechanical properties applied in modelling

\begin{tabular}{lcc|c|c}
\hline \multicolumn{1}{c|}{ Stratigraphy $(\mathrm{m})$} & $\begin{array}{c}\text { Bulk density } \\
\left(\mathrm{kN} / \mathrm{m}^{3}\right)\end{array}$ & $\begin{array}{c}\text { Cohesion } \\
(\mathrm{kPa})\end{array}$ & $\begin{array}{c}\text { Friction angle } \\
\left({ }^{\circ}\right)\end{array}$ & $\begin{array}{c}\text { Elasticity } \\
\text { modulus } \\
(\mathrm{kPa})\end{array}$ \\
\hline $\begin{array}{l}\text { Colluvium and } \\
\text { anthropogenic deposits }\end{array}$ & 21.6 & 16 & 23.5 & 9000 \\
Glacial till & 21.6 & 15 & 29.9 & 19250 \\
Sandstone (1) & 20.7 & 4 & 29.5 & 36080 \\
Clay (1) & 20.7 & 135 & 20.6 & 27570 \\
Sandstone (2) & 20.7 & 4 & 29.5 & 36080 \\
Clay (2) & 21.3 & 135 & 20.6 & 27570 \\
\hline
\end{tabular}




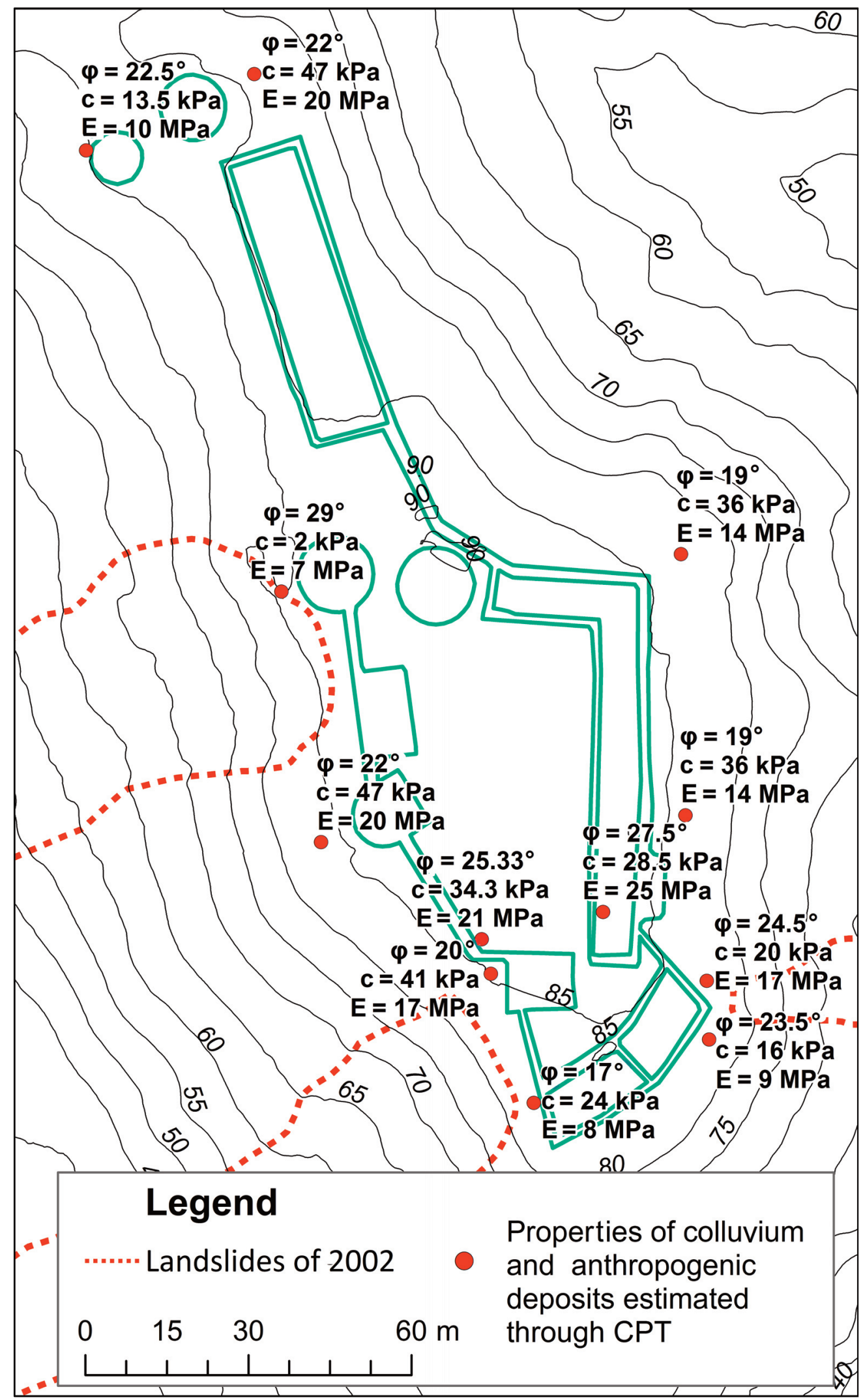

Fig. 3. Geomechanical properties of colluvium and anthropogenic sediments determined in 12 points from cone-penetration tests (CPT) (compiled after Mūrnieks et al. 2002; LGIA 2015). 


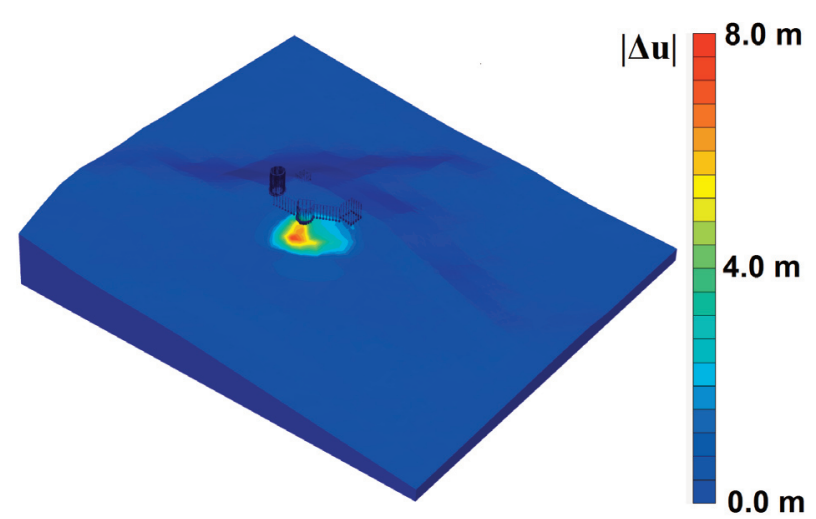

Fig. 4. The most landslide-susceptible zone in bedrock displayed through shadings of the total displacement increments $(|\Delta \mathrm{u}|)$.

hard bedrock is simulated. Modelled incremental displacements in the plastic phase indicate zones where slope failures can potentially develop (Fig. 6).

Figure 6 illustrates modelled deformations of soil material. Contrary to limit-equilibrium analysis, where the stability of a rigid soil body is determined, finite-element simulation considers the impact of stress redistribution in the soil massif from the plastic simulation phase on the slope stability in the subsequent safety phase. One can observe that the most intense displacements on the western slope at the foot of the defence tower may occur where the weakest zone of bedrock was identified. Another potential landslide can develop on the southern slope with a relatively steep slope angle and high elevation of the slope.

The subsequent slope stability model of the colluvial material is explicitly illustrated in Fig. 7.

Contrary to the stability of bedrock, where the most unstable zone in the westernmost part of the castle mound was identified, the most susceptible slope stability zone for colluvium and anthropogenic cover is located on the southern slope of the castle mound. The section through this zone is drawn in Fig. 8.

The estimated safety factor $\sum M s f$ of this slope section equals 1.269 , which is significantly lower than for bedrock stability. Moderate shear strength parameters were assumed in the simulation, however, Fig. 3 illustrates that the geomechanical properties of colluvial material can be significantly lower in other locations.
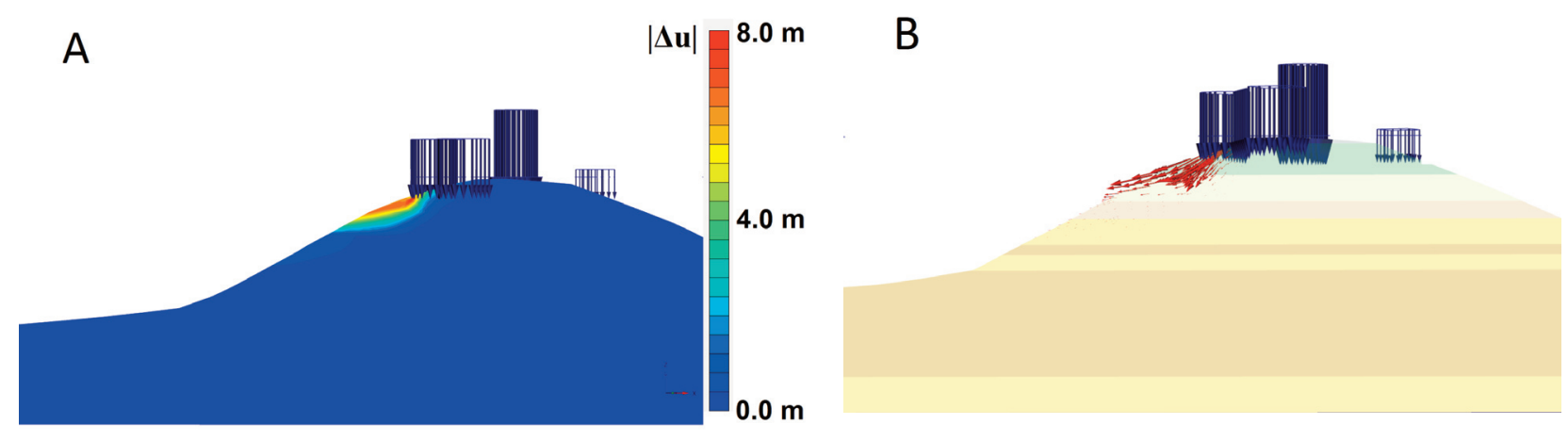

Fig. 5. The modelled sliding surface in the most landslide-susceptible section in Devonian bedrock visualized through shadings of the total displacement increments $(|\Delta \mathrm{u}|)(\mathbf{A})$ and displacement vectors $(\mathbf{B})$.

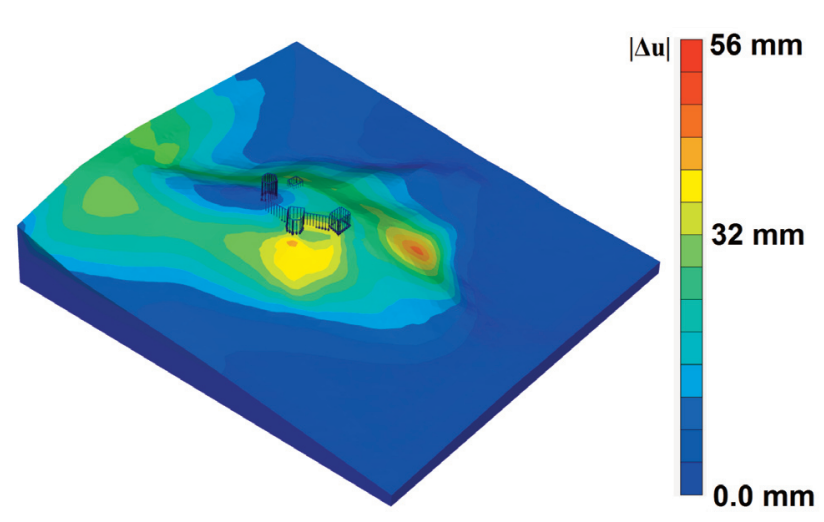

Fig. 6. Modelled plastic deformations of colluvial material visualized through shadings of the total displacement increments $(|\Delta \mathrm{u}|)$.

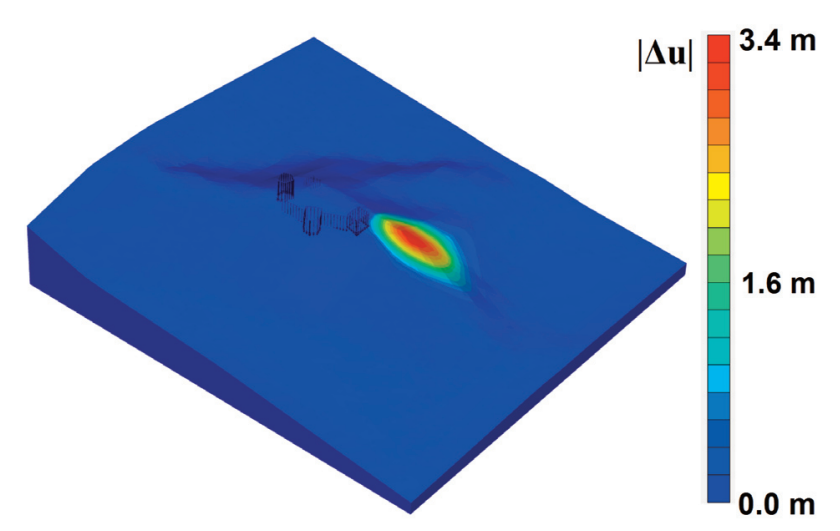

Fig. 7. Slope stability of colluvial material visualized through shadings of the total displacement increments $(|\Delta \mathrm{u}|)$. 


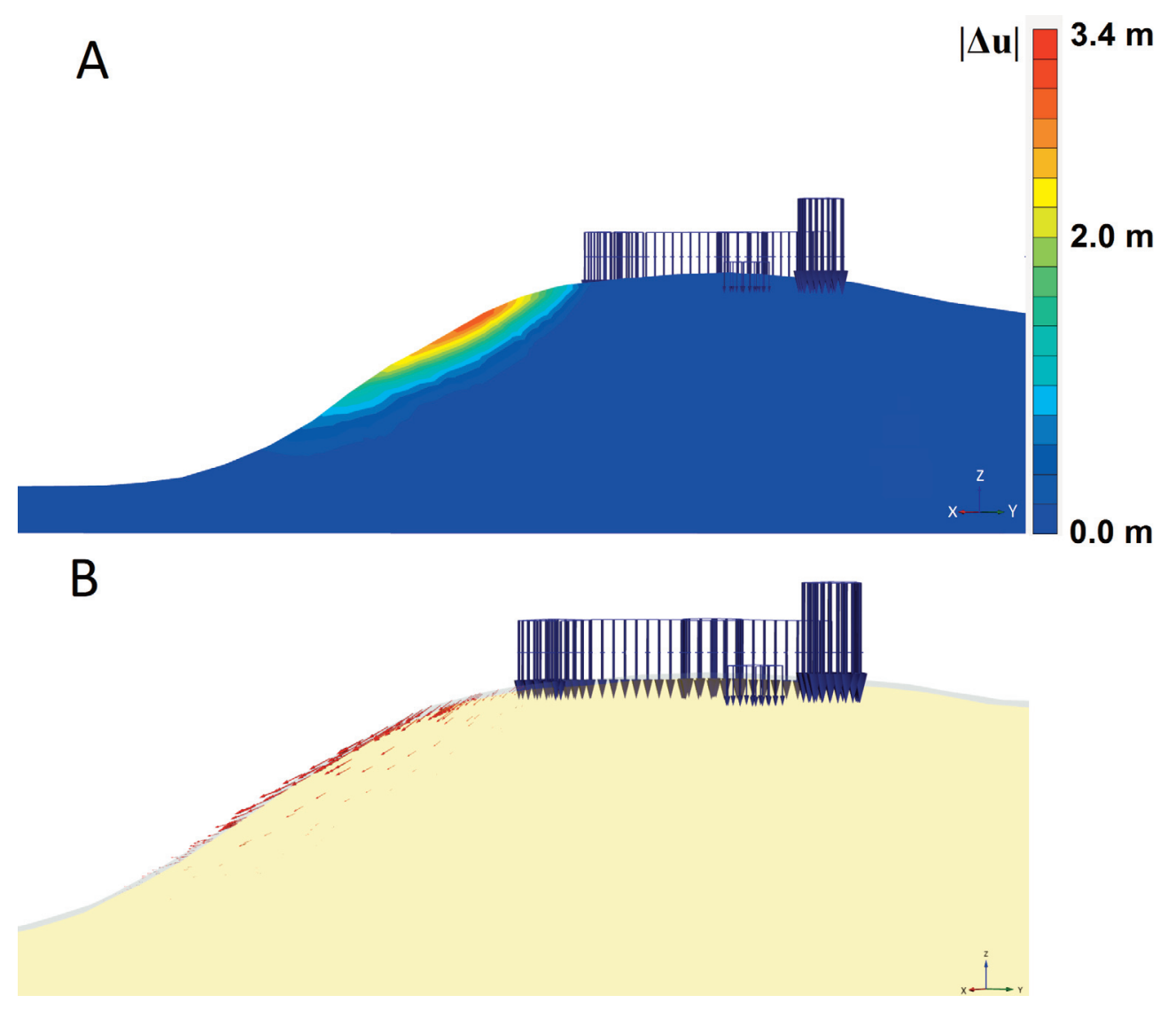

Fig. 8. The modelled sliding surface in the most landslide-susceptible section in colluvium visualized through shadings of the total displacement increments $(|\Delta \mathrm{u}|)(\mathbf{A})$ and displacement vectors $(\mathbf{B})$.

\section{DISCUSSION}

This study employs the newest slope stability modelling techniques in estimating the slope stability of the Turaida castle mound in Central Latvia. Dangerous landslides affected the Turaida castle mound in quick succession in 2002. Three landslides were formed in different locations of the castle mound without any pronounced seismic activity. One common factor for all landslides was that they occurred in colluvium and anthropogenic deposits on the slopes during wet and cold season. Hydrogeological landslide triggers were investigated in detail in Kukemilks et al. (2018) and subsequently a 2D slope stability simulator was applied.

The finite-element 3D slope stability model of the Turaida castle mound demonstrates the application of state-of-the-art geomechanical models in hillslopes with complex topography and geology. In complex morphological and lithological settings, such as the Turaida castle mound, the identification of the most landslide-prone hillslope section using 2D analysis is hardly possible. The
3D finite-element model identifies the most landslideprone zone fully automatically, considering both lithological and morphological factors. This is one of the most important advantages over conventionally used analysis where 2D hillslope sections are arbitrarily selected. Moreover, 2D models frequently underestimate slope stability, however, 3D models simulate the movement of the complete landslide body attaining more realistic safety factors.

Several assumptions were necessary when building a 3D numerical model of the castle mound. Due to meshing restrictions, coarse model's topography was applied, while thin interlayers and sediment leans were not considered in the model. Fully saturated soil was assumed in the geomechanical model to avoid the overestimation of slope stability due to suction force. Slope stability increase due to suction force alternates depending on temporarily variable precipitations, and therefore it was avoided in the stability model.

Due to numerical restrictions, two modelling scenarios were employed: (1) stability of bedrock on which the castle is supported and (2) stability of colluvium 
where the landslides of 2002 were located. Thus, two different landsliding mechanisms were considered in the study: (1) deep-seated landslides in bedrock and (2) shallow landslides in colluvium and anthropogenic deposits.

According to the first modelling scenario, the most landslide-prone zone of bedrock is located in the western slope at the foot of the defence tower. The safety factor $\sum M s f=1.626$ indicates that the safety of this section is sufficient, however, there are concerns about the geomechanical properties applied in the model. The geomechanical properties of bedrock were determined in only one borehole in the central part of the castle mound, therefore it is not clear whether the same properties are applicable to the outermost zones of the castle mound. On outer zones close to the surface, bedrock can have lower shear resistance due to tree roots penetrating rock, weathering caused by flowing groundwater and freezing and thawing of pore-water. Using a 2D slope stability model, Kukemilks et al. (2018) also identified elevated landslide risk in this zone, however, the $2 \mathrm{D}$ analysis provided a slope safety factor of 1.112 , which is significantly lower. This difference can originate from differences between 2D and 3D models, because 2D analysis frequently delivers lower safety factor values than 3D modelling. Another reason could be a more pessimistic approach concerning groundwater conditions, because in the analysis by Kukemilks et al. (2018), an additional 3D groundwater model was elaborated and the highest pore-water pressures were considered in the model. Therefore, further investigation would be necessary for the determination of the geomechanical properties in various locations of the castle mound.

The second modelling scenario simulates landsliding in colluvium and anthropogenic cover of the castle mound as it was observed in the previous landslides. The safety factor equalling 1.269 illustrates that the stability of colluvial material is not sufficient, because under unfavourable conditions, the safety factor can decrease below 1.0. This scenario indicates that shallow landslides are most possible on the southern slope of the castle mound. Uniform thickness of colluvium equal to $1.5 \mathrm{~m}$ was assumed for this modelling scenario. However, the actual depth of colluvium and anthropogenic deposits strongly varies depending on location. Therefore, the investigation of the real depth of colluvial material, e.g. by using geophysical surveys and drillings, would be necessary for the estimation of actual slope stability.

Due to complex topography of the castle mound, the mesh of the 3D stability model was relatively coarse, meaning that some small-scale landslide-susceptible zones may have been overlooked. To avoid model's coarseness, separation of the mound into several smallscale segments and inspection of local morphological, lithological and hydrogeological characteristics would be necessary. Separation of the model would also allow the identification of several landslide-susceptible hillslope zones, because Plaxis determines only one landslide in the model's domain. Also, exact estimation of the geomechanical parameters, both in bedrock and colluvium during additional fieldwork, is necessary for adequate geotechnical investigation of the actual stability of the mound.

High saturation of the hillslope and consequent increased pore-water pressures may develop as a result of intense snowmelt and rainfall. Less conductive colluvial material may serve as a barrier preventing drainage of groundwater from conductive sandstone layers and consequently causing elevated pore-water pressures in the hillslope. These hydrogeological factors were not considered in the analysis because it was numerically not possible to couple both multilayer bedrock and colluvial material in one $3 \mathrm{D}$ model. The perched groundwater tables that developed due to thin, less permeable interlayers were also omitted from the model because considering them would demand very fine model discretization, long simulation time and convergence issues. In the subsequent studies, the 3D stability model can be downscaled to separated hillslope segments and applied in conjunction with 3D groundwater models. Inclusion of thin, less permeable interlayers allows for the evaluation of the impact of heterogeneous groundwater conditions on the 3D stability of the castle mound. It should be added that in stability analysis with Plaxis $3 \mathrm{D}$, only one potential landslide is determined in the model's domain. Nevertheless, other landslide-susceptible zones of the castle mound may have been overlooked in the analysis. Therefore, for detailed safety modelling the castle mound can be separated into several smaller segments and detailed-scale analysis with finer mesh can be conducted.

\section{CONCLUSIONS}

The 3D slope stability model of the Turaida castle mound demonstrates the application of the state-of-the-art geomechanical models such as Plaxis 3D. The model allows a fully automatic identification of the most landslide-threatened hillslope sections, contrary to $2 \mathrm{D}$ analysis where slope stability sections are arbitrarily selected. The main advantage in comparison with $2 \mathrm{D}$ models is automatized identification of the most landslide-prone zones when many factors are affecting hillslope, such as irregular topography, complex lithology, external loads, etc. The 3D finite-element method allows determination of stress and strain distribution in the landslide's body, which brings the simulation closer 
to real-word conditions. However, the advantages of 3D models can be fully used if high-quality geological data are available. Many assumptions were made to represent complex geological and topographical conditions of the entire castle mound in a single model and to reach model's convergence. Therefore, the downscaling of the model to separated hillslope segments may be necessary for the improvement of the accuracy of modelling results.

Acknowledgements. We would like to thank the company 'SIA MikroKods' for supporting us with modelling software and the engineering office 'SIA Inženieru birojs Būve un forma' for providing us with their computational facilities. The referees Vitālijs Zelčs, Juris Soms and an anonymous referee are acknowledged for constructive comments on the manuscript. The publication of the article was funded by the Open Access Fund of Universität Trier, the German Research Foundation (DFG) within the Open Access Publishing funding programme and the Estonian Academy of Sciences.

\section{REFERENCES}

Āboltinšs, O. 1971. Razvitie doliny reki Gauya [Development of the Gauja River Valley]. Zinātne, Riga, 104 pp. [in Russian].

Baligh, M. \& Azzouz, A. 1975. End effects on stability of cohesive slopes. Journal of Geotechnical Engineering Division, 101, 1105-1117.

Cheng, Y. \& Yip, C. 2007. Three-dimensional asymmetrical slope stability analysis extension of Bishop's, Junbu's, and Morgenstern-Price's techniques. Journal of Geotechnical and Geoenvironmental Engineering, 133, 1544-1555.

Das, B. M. 1998. Principles of Geotechnical Engineering, 4th edn. PWS Publishing Company, Boston, 736 pp.

Fredlund, M., Fredlund, D. G. \& Zhang, L. 2017. Moving from 2D to a 3D unsaturated slope stability analysis. In Proceedings of the 2nd PanAmerican Conference on Unsaturated Soils (Hoyos, L. R., McCartney, J. S., Houston, S. L. \& Likos, W. J., eds), pp. 136-145. American Society of Civil Engineers, Dallas, Texas.

Gens, A., Hutchinson, J. \& Cavounidis, S. 1988. Three-dimensional analysis of slides in cohesive soils. Géotechnique, $\mathbf{3 8}$, $1-23$.

Griffiths, D. V. \& Lane, P. A. 1999. Slope stability analysis by finite elements. Géotechnique, 49, 387-403.

Hovland, H. 1977. Three-dimensional slope stability analysis method. Journal of the Geotechnical Engineering Division, 103, 971-986.

Kalatehjari, R. \& Ali, N. 2013. A review of three-dimensional slope stability analyses based on limit equilibrium method. Electronic Journal of Geotechnical Engineering, 18, 119134.
Kohv, M., Talviste, P., Hang, T., Kalm, V. \& Rosentau, A. 2009. Slope stability and landslides in proglacial varved clays of western Estonia. Geomorphology, 106, 315-323.

Kohv, M., Talviste, P., Hang, T. \& Kalm, V. 2010. Retrogressive slope failure in glaciolacustrine clays: Sauga landslide, western Estonia. Geomorphology, 124, 229-237.

Kukemilks, K. 2018. Landslide inventory in the Abava spillway valley, Latvia. Estonian Journal of Earth Sciences, 67, 165175.

Kukemilks, K. \& Saks, T. 2013. Landslides and gully slope erosion on the banks of the Gauja River between the towns of Sigulda and Ligatne. Estonian Journal of Earth Sciences, 63, 231-243.

Kukemilks, K., Wagner, J.-F., Saks, T. \& Brunner, P. 2018. Physically based hydrogeological and slope stability modeling of the Turaida castle mound. Landslides, 15, 2267-2278.

LGIA. 2015. Open LiDAR data, scanned in 2015. Available at https://www.lgia.gov.lv/lv/Digit\%C4\%81lais\%20virsmas\%20 modelis [in Latvian; accessed 30 October 2020].

Lu, N. \& Godt, J. W. 2013. Hillslope Hydrology and Stability. Cambridge University Press, Cambridge, 458 pp.

Mūrnieks, A., Meirons, Z., Lācis, A. \& Levins, I. 2002. Pārskats par Turaidas pilskalna, tā apkārtnes geologisko, hidrogeologisko un inženiergeologisko izpēti [Technical Report of Geological, Hydrogeological and Engineering Geological Investigation of the Turaida Castle Mound and Its Vicinity]. Latvian Environment, Geology and Meteorology Centre, Riga, 102 pp. [in Latvian].

Soms, J. 2006. Regularities of gully erosion network development and spatial distribution in south-eastern Latvia. Baltica, 19, 72-79.

van der Sloot, M. 2019. Ignoring suction after a fully coupled flow-deformation analysis in Safety analysis gives incorrect stresses in PLAXIS 2D [Solved]. Available at https://communities.bentley.com/products/geotech-analysis/w/plaxissoilvision-wiki/45789/ignoring-suction-after-a-fully-coupledflow-deformation-analysis-in-safety-analysis-gives-incorrectstresses-in-plaxis-2d-solved [accessed 30 October 2020].

van der Sloot, M. 2020. PLAXIS 3D CE V21.01: 1 - Tutorial Manual.pdf, Chapter 5: Construction of a road embankment. Available at https://communities.bentley.com/products/geotechanalysis/w/plaxis-soilvision-wiki/46137/manuals---plaxis [accessed 18 November 2020].

Zelčs, V. \& Markots, A. 2004. Deglaciation history of Latvia. In Quaternary Glaciations - Extent and Chronology, Part I: Europe (Ehlers, J. \& Gibbard, P. L., eds), pp. 225-243. Elsevier B.V., Amsterdam.

Zelčs, V., Markots, A., Nartiss, M. \& Saks, T. 2011. Pleistocene glaciations in Latvia. In Developments in Quaternary Science. Quaternary Glaciations - Extent and Chronology. A Closer Look, Vol. 15 (Ehlers, J., Gibbard, P. L. \& Hughe, P. H., eds), pp. 221-229. Elsevier B.V., Amsterdam. 


\section{Läti Turaida lossimäe nõlvade püsivuse 3D-mudel}

\section{Kārlis Kukemilks ja Mārtiņš Viln̄itis}

On uuritud Plaxis 3D tarkvara abil Läti Turaida lossimäe nõlvade püsivust ja maalihete tekkimise põhjusi. Arvutisimulatsiooni käigus analüüsiti mäe stabiilsust ja määrati nõlvade kõige varisemisohtlikumad tsoonid. Kasutatud 3D lõplike elementide meetodil on märkimisväärsed eelised, võrreldes traditsioonilise 2D-meetoditega, kus läbilõigete valik on subjektiivne. Töö käigus modelleeriti kaks nõlva stabiilsuse stsenaariumi: aluspõhjakivimitesse ulatuv maalihe ja pinnakatte kolluviaalse materjali maalihe. 3D-mudel näitas, et kolluuviumis on maalihked tõenäolisemad ja nõlva ebapüsivus on seotud kolluuviumi kõige nõrgema tsooniga. Turaida lossimäe maalihked on varasemalt just sellisel viisil toimunud. Mudeli füüsikaline alus võimaldas saada tulemusi, mis on väga lähedased looduslikele tingimustele. Seetõttu annab kasutatud meetod maalihete tekkimise mehhanismidest hea ülevaate. 